\title{
Glocalizing' the Hijab: A Malaysian Perspective
}

\author{
Nurzihan Hassim ${ }^{l, *}$ \\ ${ }^{1}$ Department of Media Studies, Faculty of Arts and Social Sciences, Universiti Malaya, Malaysia
}

\begin{abstract}
This article examined the hijab, or the act of veiling as a transformative socialization agent for Malay-Muslims in Malaysia's multicultural state. Through the media, the hijab was purported as a progressive lifestyle with representations of veiled Muslim women who are predominantly Malay. Apart from upheavals of Islam and the globalization of veiling across Muslim-majority countries, local socio-political developments have commodified the hijab as a product of Malay sovereignty rather than a symbol of religious obligation. Malay-Muslim women are predisposed to media messages that altered conservative Malay-Muslim stereotypes through convergence of old and new media platforms. The article explores the local hijab phenomenon by examining its media movement and its influence towards attitudes and behaviours of audiences. The evolution and visibility of the hijab are analyzed in relations to multiplicity of the Malay-Muslim identity and its integration with transcultural ideas of the East and West. Findings indicate that acceptance of this dynamic cultural identity resonate through diversity of content and multitudes of accessibility.
\end{abstract}

\section{Introduction}

The 'hijab', or the act of veiling in its true intention protects a Muslim woman's modesty, both physically and mentally. Translations from the Quran describe cloaking the body to avoid harassment from the opposite sex and displaying religious devotion [1], where the An-Nur verse read, “...O Prophet! Tell thy wives and daughters, and the believing women, that they should cast their outer garments over their persons (when abroad): this is most convenient, that they should be known (as such) and not molested (33: 59)" [2]. In recent years, Muslim-majority countries have revived female modesty as a uniform for cultured, modern Muslim women to illustrate Islam as a progressive religion in comparison to its Western counterparts; in addition to using the hijab as a form of solidarity against Islamophobia. Al-Jazeera, a news organization based in Qatar responded to the headscarf ban controversies in France through the hijab worn by its presenters and prevalence of similar issues in its news content [3]. Consequently, in Europe and parts of Australasia where Muslims are the minority, "others" have grown accustomed and appreciative of hijab as an ethno-religious signifier that created a window for them to learn more about Islam rather than condemn it [4]. The emergence of the hijab as a cultural artefact has created a unique global movement for female modesty and lent a voice to Muslim women whom

* Corresponding author: nurzihan@siswa.um.edu.my 
were mostly cloaked in patriarchal stereotypes and "backwardness" from the ancient practice of veiling.

On the other hand, anxieties in cultivating more bohemian and inclusive Muslim society saw a series of capitalist ventures that reversed the media flows from the East to West. Evidence from a Thomson Reuters 2014-2015 report suggest that Muslim fashion is growing rapidly with USD 266bil spent on clothing and footwear, while this figure is expected to multiply by 2019 [5]. International retailers such as $H \& M, D K N Y$ and Dolce \& Gabbana have acknowledged its Islamic consumers by introducing clothing lines that are designed for the Middle-Eastern market in efforts to elevate the status of the hijab and have it eliminated from prejudicial perceptions [5,6]. Meanwhile, in Asia, Indonesia is renowned for neo-traditional Islamic fashion that are endorsed by celebrities and clerics in mass media, of which is also being exported back to the Middle East [7]. Subsequently, Dian Pelangi, a leading designer of modest fashion was named one among the top 500 people in fashion from by UK-based magazine, Business of Fashion through her self-named hijab label [8]. It can be seen that the reach of modest fashion have extended to even non-Muslim Asian regions as illustrated by Japanese company Uniqlo in their collaboration with Muslim designer Hana Tajima in a worldwide launch of scarfs, inners and kaftans that are modeled by Yuna, an international, Malaysian-born singer that is considered as a role model for hijab fashion enthusiasts.

Similarly, Malaysia is experiencing a climate of 'hijab elite' through the widespread growth of hijab brands. As an example, Fareeda recorded revenue of MYR30million (USD8mil) in 2013 alone [9] by marketing luxurious hijab designs that are catered to highprofile and affluent wearers. In the same way, several other hijab-specific business empires such as Naelofar Hijab and dUckscarves established by notable media personalities; Neelofa Mohd Noor of and Vivy Yusof respectively, have produced exclusive hijab that are catered to the millennial middle-class Malays in the aim to remove unfavourable perceptions upon veiling that were normally donned by elderly, unfashionable MalayMuslim "makciks" (aunties). For Naelofar, the family business gained profits through 700 distributors nationwide and has now reached buyers in both Asian and European countries and soon, the United States, through the availability of social networking [8]. Meanwhile, the scarcity of hijab with upscale, international styles inspired Vivy Yusof of $d U c k s c a r v e s$ to design modern, Malaysian-flavoured scarves for empowered, professional women that is also applicable for style-savvy non-Muslims. Another essential factor that contributes to the steadfast hijab movement is the move by media figures such as Neelofa and Vivy to start veiling after achieving their celebrity statuses. Practicing modesty after reaching a certain stage of adulthood is considered common in Malaysia as veiling remains an option to Malay-Muslim adults despite Islam being a birth religion to all Malays [10].

In addition to this recursive pattern, advent of networking sites like Facebook, Twitter and Instagram corresponds to the use of traditional media in Malaysia. Hijab-centric television programmes such as "Hijabku Gayaku" and ground-breaking magazines like Hijabista [11] displayed veiling as a widely-accepted regime for urban Malay-Muslims, although its more contemporary depiction is relevant to a limited pool of Malay audiences. In brief, the unyielding competition of hijab marketing in Malaysia may have excluded the working-class and reconstructed the Malay-Muslim identity in the public sphere as a determinant of social status. This article reviews the diminishing role of hijab as the observance of faith, whereby audiences' desires of social inclusion is slowly replacing the importance of modesty. 


\section{Redefining 'Malayness'}

More often than not, urban hijab representations in Malaysian media today are encouraging young Malay women to be liberated and experimental with their veiling choices in the emphasis to appear modern and unique. While Islamic modesty conceals sexual elements of the female body, artistic interpretations of the hijab are going beyond boundaries that are not necessarily sharia-compliant. As seen in depictions of hijab in magazine spreads, the focus was on emulating international fashion magazines in its feminist stance and resistance towards traditionalist views of Malay-women [12]. The traditional role of Malay women as head of the household and purveyor of moral values to young children is absent in the reproductions of the hijab as a symbol of feminist manifestations that seek to explore her sexuality in the hijab.

Despite bearing strong colonial influences, Malaysia has negotiated multicultural identities since its independence but the mainstream media often compartmentalized the core-cultures of Malays that define the bumiputera (sons of the soil) under legislations of Barisan Nasional that are often Malay-centric [13]. Malay-Muslim women often relinquished their religious upbringing from the villages in favour of job opportunities and more modern lifestyles during the New Economic Policy that favoured progress of the Malays in the $1970 \mathrm{~s}$, but have since transitioned to the former. In its place, the revival of Islam in the 1980s motivated Malay undergraduates to participate in religious social movements with Angkatan Belia Islam Malaysia (ABIM) and dress in modest clothing such as the jubah (loose dress) and tudung (veil) [14]. As Islam further exposed audiences to religious content on broadcast and print media, the integration of Islam in administration and politics through Islam Hadhari that was introduced by former Prime Minister, Dato Seri Abdullah Ahmad Badawi had possibly magnified the need for Malays to be represented as Muslims. In a study by Martin [15], the proliferation of Muslim-living keenness in Malaysia observed that youths now no-longer acknowledge themselves as Malays per se, but as new Muslims instead.

As marketing of halal products in Malaysia became a norm, emergence of the hijab in the media was agency to the group identity of Malay 'hijabis'. Authors have contended that despite flailing numbers, the excess of womens' magazines are catalyst to consumerism and commodification [16-18]. These publications present the construct of ideal womanhood through glamorous clothing and makeup, and subsequently wearing the hijab is considered as a privilege where its significance is measured from its connection to popular culture and materialism [19]. Loo established that capitalist media retain the essence of Malay-Muslims through shared language, cultural heritages, and social history [20], therefore the negotiation of Malayness in the new economy of veiling lies upon the desire for young Malay-Muslims to remain ethnically dominant within a changing community of imported fads and trends; particularly Islamisation and Arabicization of the nation state which now in its coercion reassures "others" that hijab is no more backward. The exclusivity of the hijab is perceived by highly educated women as proponents of egalitarian Islamic ideologies as the objectifications of women's bodies in media determine audiences' expectations of their self and govern their self-confidence [21]. As described by Khoo in Reclaiming Adat [22], Malay women were established as "bumigeois" where they struggle to maintain their traditional ways whilst integrating their self-image with current forms of Islam that are pervasive in local media experiences.

\section{3. 'Glocalizing' the Hijab}

After examining the conceptual term of 'glocalisation' discussed by Roland Robertson [23], it can be said that the integration of hijab in the Malay-Muslim society is a phenomenon that blended oppositions. Considering global outlook on the hijab and its immersivity with 
local conditions, the hijab can be linked to the concept of hybridity that matched best practices from different cultures or patterns that form new subcultures that are anticipated to inspire improved life qualities. The acculturation of Malay-Muslims towards Islam are from conditions regulated by its state policies, while glocalisation mediated 'cultural pluralism' to accommodate social and cultural differences that arise in the multi-ethnic landscape. An illustration of glocalization is Rupert Murdoch's acquisition of Star TV, a merger that was pervasive with Anglo-American content but sustained Asian presenters to display a sense of ethnic loyalty to its audiences and transcend boundaries of culture in its delivery of information [24]. In the same way, the hijab converged with Malay traditions to form a more demure, Pan-Arabic identity to project Islamic solidarity whilst also being equally progressive and tolerant of others, outspoken and adaptable to any challenges as their Western peers despite the limitations of veiling.

Even so, the hijab is not often accepted as positive reinforcement. In contrast to religious teachings that subdue materialistic wants and needs; merchandising of the hijab saturated into a form of brand identity and sought attention in the public sphere. The idiosyncrasy of subjugating oneself to God and yet displaying the very ornaments that the religion aims to conceal from the opposite sex, has streamlined the hijab as a malevolent representation of Malay-Muslim altogether. Marina Mahathir, a womens' rights activist criticized glocalization of Arabic identity as a form of colonialization in itself thus undermining Malay women, particularly those in the hijab from freely participating in social activities as there are morals to observe behind their veiling [25]. Even in social media, a status post by the Facebook page of MizanSisters, an online community for Muslim women contained an 'open letter' criticizing Hijabista magazine from an anonymous writer named 'A Worried Muslimah'. The magazine was accused by netizens as a mockery of religion by fashionizing of the hijab in garish visuals that are only beautiful aesthetically but fail to prove its functionality to the lives of young Muslim women [26]. Further to this, the status mobility offered by veiling to urban audiences have, in some cases backfired; specifically in how proprietors of the Fareeda company had taken pride in disconcerting behaviours of its patrons in the unforeseen mob that ensued during the recent launch of its premium hijab design called Sweet Love. Although the video of the incident posted on its Facebook page meant to illustrate the credibility and impact of its brand identity, affected Fareeda hijab fans were likened to lowly herds of mindless 'cattle' in responses by opinion leaders and audiences [27]. It can be seen that from these few examples that media audiences are active participants in the discourse of female modesty in Malaysian media, specifically on the Internet that allows instantaneous feedback and channels of rapid information delivery.

Commodification of the hijab as a symbol of wealth and stature is now a moral dilemma as to how Malay-Muslim women incorporate wealth and material desires in their submission to Allah. Although veiling is presently common among Malay-Muslim women, it takes self-consciousness to proclaim the hijab as a symbol of freedom for each individual and it also takes into account the level of participation by the hijabi audience in media. Reinforcement of the hijab identity through media recommendations and exchange of messages with other members of the community through the media determines whether the voice heard in the public sphere is meant to benefit the modesty movement as a spiritual initiative or merely for personal gain to boosting one's ego and emotional well-being. Kulenovic asserts that this is a form of 'projective identity' [28], where social agencies from cultural materials redefine an individual's place in the society and transform the overall social structure altogether. 


\section{Conclusion}

The resurgence of Islam in many parts of the world ordained female modesty as a symbol of retaliation against Islamophobia and criticizes Muslim stereotypes of female oppression $[10,14]$. Similarly, modern hijab representations in Malaysian media are preoccupied with the reinvention of the Malay-Muslim community through their cultural resistance to colonial ties. By projecting a hybriditized identity of the hijab, the identity projects Malay supremacy and underterring gender empowerment. While Ang contended that the import of external practices and forms supplemented by media developments are re-organized around "the commercial principle of production of culture for profit" or commodification [29], the growing influence of hijab in a progressive Malaysian environment with increasing media capacities have re-traditionalized the role Malays as modern and more intellectual Muslims [30]. With a more globalized outlook on the hijab as signifier of female Muslims, the accessibility of the Internet played a key role in resonating the modern hijab as a form of self-expression in the minds of urban Malay-Muslim women. The hijab phenomenon in Malaysia can be seen a relapse of identity influenced by the country's Muslim-centric progress. The term "Malay-Muslims" is a form of Malay supremacy in its symbolism, and the shift in power from the last thirty years have also amplified the hijab as a culmination of Malayness in its negotiation with a multicultural society. Through their persistence as a hijabi, veiled Malay women seek to be treated equally and most capably whilst remaining relevant in the global media capitalization on the hijab.

\section{References}

1. M. Woldesemait, The Rhetoric of the Modern Hijab, (2012)

2. T. F. Ruby, Listening to the voices of hijab, Womens. Stud. Int. Forum, 29, 54-66, (2006)

3. S. Cherribi, From Baghdad to Paris: Al-Jazeera and the Veil, The Harvard Int. J. Pres/Politics, 11, 121-138, (2006)

4. E. Tarlo, Hijab in London: Metamorphosis, Resonance and Effects, J. of Material Culture, 12, 131-156, (2007)

5. F. Naib, "Sweden's 'hijabista': Selling Muslim fashion," ALJAZEERA, (2015)

6. N. Agrawal, "Dolce \& Gabbana Launched A Line Of Hijabs And Abayas, But Something's Off," Huffpost Style, (2016)

7. E. F. Amrullah, Indonesian muslim fashion Styles \& Designs, ISIM Review, 22, (2008)

8. Kate Mayberry, "BBC - Capital - How Muslim headscarves became a fashion empire," $B B C, 2015$. [Online]. Available: http://www.bbc.com/capital/story/20151214-howmuslim-headscarves-became-a-huge-fashion-empire. [Accessed: 12-Apr-2016]

9. S.L. Boo, "Tudung Industry in Malaysia: Cashing in conservative Islam," The Malay Mail Online, 2015. [Online]. Available: http://www.themalaymailonline.com/malaysia/article/tudung-industry-in-malaysiacashing-in-on-conservative-islam. [Accessed: 01-Apr-2016].

10. A. Ong, State versus Islam: Malay Families, Women's Bodies, and the Body Politic in Malaysia, Am. Ethnologist, 17, 258-276, (1990)

11. S. Harian, "HIJABISTA, majalah pertama dunia fesyen berhijab di Malaysia Nasional - Sinar Harian," 2012. [Online]. Available: http://www.sinarharian.com.my/nasional/hijabista-majalah-pertama-dunia-fesyenberhijab-di-malaysia-1.41541.

12. N. Hassim and N. L. Khalid, "Stailo \& Sopan : Modesty and Malay-Muslim Women, Int. Conference on Trends in Soc. Sci. Bus. and Humanities (TSSH-2015), (2015)

13. M. Stivens, 'Family values' and Islamic revival: Gender, rights and state moral 
projects in Malaysia," In Women's. Stud. Int. Forum, 29, 354-367, (2006)

14. R. Khalid and M. O'Connor, The Hijab: Representation among the Muslim Women in Malaysia," in The Second Asian Conference on Arts and Humanities, (2011)

15. D. Martin, Redefining Malayness: Expectations of Young-Adult Malaysian Muslims," in Thinking Through Malaysia: Culture \& Identity in the 21st Century, Petaling Jaya: Strategic Inf. and Res. Dev. Centre, 31-49, (2012)

16. U. Khattab, "Saya Happy: Re-reading the Promotion of Female Identity in Local and International Women's Magazines-a semiotic study," e-Journal Soc. \& Behav. Res. in Bus., 3, 14-28, (2012)

17. F. Boni, Framing media masculinities men's lifestyle magazines and the biopolitics of the male body, European. J. Comm., 17, 465-478, (2002)

18. S. Kassam, Marketing an imagined Muslim woman: Muslim Girl magazine and the politics of race, gender and representation, Soc. Identities, 17, 543-564, (2011)

19. B. Gökarıksel and A. J. Secor, New transnational geographies of Islamism, capitalism and subjectivity: the veiling-fashion industry in Turkey," Area, 41, 6-18, (2009)

20. H. C. Loo, G-SEC WORKING PAPER No. 18 Corrupting the culture of denial?: A trans-ethnic cinematic representation and transformation of Malay/sian nationalism in independent film-making, (2007)

21. S. Wok and S. Mohd, The impact of TV and magazine on fashion and dressing of urban women of different ages, Jurnal Pengajian Media Malaysia, 10, 157-170, (2008)

22. G. C. Khoo, Reclaiming adat: Contemporary Malaysian film and literature. Vancouver: UBC Press, (2006)

23. R. Robertson, Glocalization: Time-space and homogeneity-heterogeneity, Glob. Mod., 25, 25-45, (1995)

24. F. Terry, Understanding Global Media. London: Palgrave MacMillan, (2007)

25. S.L. Boo, "Marina Mahathir: Malaysia undergoing 'Arab colonialism' | Malaysia | Malay Mail Online," 2015. [Online]. Available: http://www.themalaymailonline.com/malaysia/article/marina-mahathir-malaysiaundergoing-arab-colonialism. [Accessed: 04-Oct-2015].

26. N. Hassim, A Comparative Analysis on Hijab Wearing in Malaysian Muslimah Magazines, J. South East Asia Rese. Center Comm. and Humanities, 6, 79-96, (2014)

27. N. Bakeri, "Pelanggan 'merusuh' rebut giliran beli tudung, promosi Fareeda dipertikai," Astro Awani, 2016. [Online]. Available: http:/www.astroawani.com/gayahidup/pelanggan-merusuh-rebut-giliran-beli-tudung-promosi-fareeda-dipertikai100847. [Accessed: 08-Apr-2016].

28. T. Kulenović, A veil (hijab) as a public symbol of a Muslim woman modern identity, Collegium antropologicum, 30, 713-718, (2006)

29. I. Ang, Living room wars: Rethinking media audiences for a postmodern world. (Psychology Press, 1996).

30. A. Ong and M. G. Peletz, Bewitching women, pious men: Gender and body politics in Southeast Asia. Universiti of California Press, (1995) 